\title{
KUALITAS PAPAN PARTIKEL DARI KULIT BATANG SAGU (Metroxylon spp) DENGAN PEREKAT ALAMI ASAM SITRAT: SIFAT FISIK, SIFAT MEKANIK, DAN KEAWETAN TERHADAP RAYAP TANAH Coptotermes curvignathus Holmgren
}

(The Quality of Particle Board from Bark Fiber of Sago (Metroxylon spp) with Natural Adhesives of Citric Acid: Physical Properties, Mechanical Properties, and Durability against Subterranean Termites Coptotermes curvignathus Holmgren)

\author{
Dwi Cahyo Nugroho, Gusti Eva Tavita, Dina Setyawati \\ Fakultas Kehutanan Universitas Tanjungpura Jalan Imam Bonjol Pontianak 78124 \\ Email: dw.cahyo28@gmail.com
}

\begin{abstract}
The study aimed to analyze the quality of particle boards from bark fiber of sago (Metroxylon spp) with citric acid as natural adhesives based on physical properties, mechanical properties, and durability from subterranean termites Coptotermes curvignathus Holmgren. Particle boards are made with a size of $30 \mathrm{~cm} \times 30 \mathrm{~cm} \times 1 \mathrm{~cm}$. The experimental factors used in the study included densities $\left(0.7 \mathrm{gr} / \mathrm{cm}^{3}\right.$ and $\left.0.8 \mathrm{gr} / \mathrm{cm}^{3}\right)$ and concentrations of citric acid adhesives (20\% and 30\%). The material then flow into hotpress with $180^{\circ} \mathrm{C}$ for 15 minutes and pressure at $25 \mathrm{~kg} / \mathrm{cm}^{2}$. Testing of the physical and mechanical properties of particle boards refers to the JIS A 5908-2003 standard and durability against subterranean termites Coptotermes curvignathus Holmgren was conducted based on SNI 01. 7207-2006. The results showed that the densities factor had a significant effect on density, thickness swelling, MOE, MOR, internal bond, screw holding strength, and weight loss of the particle board against termites. Meanwhile concentration of citric acid adhesive significantly affected the density, moisture content, water absorption, thickness swelling, MOR, internal bond, and screw holding strength. The interaction between the densities factor and concentration of citric acid has a significant effect on thickness swelling and density. The physical and mechanical properties of particle boards which fulfill the JIS A 59082003 standard were density, moisture content, MOR, and screw holding strength. The durability of particleboard againts termites has a very strong level. The average values of termites mortality were $94 \% \sim 100 \%$. The average of wood weight loss values were $9.61 \% \sim 18.51 \%$. The particle board made with a density $0.8 \mathrm{gr} / \mathrm{cm}^{3}$ and concentration of citric acid adhesive $30 \%$ achieved the highest values on physical properties, mechanical properties and durability to the termites Coptotermes curvignathus.
\end{abstract}

Keywords : citric acid, Coptotermes curvignathus, Metroxylon spp, particle board, sago

\section{PENDAHULUAN}

Produktivitas hutan di Indonesia saat ini semakin menurun. Kayu sebagai bahan baku utama industri perkayuan cenderung mengalami penurunan produksi, sedangkan permintaanya semakin meningkat baik sebagai bahan bangunan atau perabot rumah tangga. Salah satu cara mengatasinya dengan mengefisiensikan pemanfaatan kayu, serta mencari alternatif melalui pengembangan teknologi pengolahan 
kayu dan seiring dengan meningkatnya permintaan masyarakat, maka pemanfaatan bahan-bahan bukan kayu yang mengandung lignoselulosa mulai dikembangkan. Lignoselulosa berasal dari limbah pertaniaan salah satunya adalah dari limbah kulit batang sagu dari hasil pengolahan batang sagu.

Tanaman sagu dapat diolah menjadi makanan pokok serta menghasilkan limbah berupa ampas dan kulit batang sagu. Limbah dari pengolahan tanaman sagu ini berupa kulit batang sagu yang belum dioptimalkan pemanfaatannya, sehingga menimbulkan permasalahan lingkungan yaitu bau yang ditimbulkan. Pemanfaatan limbah kulit sagu menjadi papan partikel merupakan suatu cara untuk meminimalisir penggunaan bahan baku kayu, dimana saat ini kayu sudah sulit untuk dijadikan bahan utama dalam perindustrian kayu. Papan partikel merupakan salah satu jenis produk komposit yang terbuat dari partikelpartikel kayu atau bahan-bahan berlignoselulosa lainnya, yang diikat dengan perekat atau bahan pengikat lainnya kemudian dikempa panas (Maloney, 1993).

Papan partikel biasanya menggunakan perekat sintetis seperti urea formaldehid, melamin formaldehid atau fenol formaldehid, padahal penggunaan perekat sintetis tersebut dapat menghasilkan emisi formaldehid yang dapat menganggu kesehatan manusia, antara lain iritasi mata, penyakit saluran pernafasan, gangguan pencernaan dan sakit kepala. Oleh karena itu, salah satu cara untuk mengurangi bahaya penggunaan formadehid adalah dengan menggunakan bahan kimia alami yaitu asam sitrat. Asam sitrat sebagai bahan pengaktif ikatan kimia dan sebagai perekat alami yang ramah lingkungan (Umemura et al., 2011 dalam Widyorini, 2012)

Widyorini et al., (2015) telah membuat papan partikel dengan konsentrasi asam sitrat 20\% dan 30\% menggunakan bahan bambu. Hasil pengujian menunjukkan bahwa interaksi kedua faktor berpengaruh nyata terhadap nilai pengembangan tebal, penyerapan air, modulus elastisitas dan modulus patah yang mana semakin bertambah besar seiring dengan semakin banyaknya jumlah asam sitrat, yang menyebabkan kekuatan perekatan dan stabilitas dimensi papan partikel menjadi semakin kuat. Kondisi optimum pada penelitiannya adalah papan partikel dengan penambahan jumlah asam sitrat $20 \%$ dapat memenuhi standar JIS A 5908 2003.

Rayap tanah merupakan jenis yang merusak kayu basah maupun kering yang berhubungan atau tidak yang dicirikan dengan adanya tanah dalam kayu yang diserang. Rayap merupakan serangga pemakan kayu (xylophagus) atau bahanbahan yang mengandung selulosa (Nandika et al., 2003). Selain itu, rayap adalah salah satu hama yang menimbulkan kerusakan hebat dan 
kerugian besar pada produk-produk kayu (Haygreen dan Bowyer, 1996).

Informasi mengenai penggunan kulit batang sagu (Metroxylon spp) sebagai bahan baku pembuatan papan partikel dan informasi mengenai rayap yang merupakan serangga pemakan kayu (xylophagus) atau bahan-bahan yang mengandung selulosa belum banyak diketahui. Oleh karena itu perlu dilakukan penelitian mengenai kualitas papan partikel dari kulit batang Sagu dengan perekat alami asam sitrat berdasarkan kerapatan yang kemudian dilakukan sifat fisik, sifat mekanik dan uji ketahanan papan partikel terhadap serangan rayap tanah Coptotermes curvignathus Holmgren.

\section{METODE PENELITIAN}

Penelitian dilakukan di Laboratorium Pengolahan Kayu di Fakultas Kehutanan Universitas Tanjungpura untuk persiapan bahan baku, Laboratorium PT. Duta Pertiwi Nusantara (DPN) untuk pembuatan papan partikel, kemudian Laboratorium Teknologi Hasil Hutan untuk pengujian serangan terhadap rayap. Penelitian dilaksanakan pada bulan Maret 2018 sampai dengan bulan Mei 2018 dari persiapan bahan baku sampai pengujian dan penggolahan data.

Bahan utama yang digunakan pada penelitian ini adalah serat kulit batang sagu yang dipotong sepanjang $1 \mathrm{~cm}$, asam sitrat, dan aquades. Papan partikel dibuat dengan ukuran $30 \mathrm{~cm}$ x $30 \mathrm{~cm}$ xl $1 \mathrm{~cm}$.

Perlakuan penelitian meliputi dua faktor yaitu kerapatan $\left(0,7 \mathrm{gr} / \mathrm{cm}^{3}\right.$ dan 0,8 $\mathrm{gr} / \mathrm{cm}^{3}$ ) dan konsentrasi perekat asam sitrat (20\% dan 30\%). Setelah semua bahan disiapkan, dilakukan pencampuran partikel dan perekat alami (asam sitrat) secara manual sampai merata. Kemudian bahan yang telah tercampur tersebut dimasukkan dalam oven kembali pada suhu $80^{\circ} \mathrm{C}$ dengan waktu \pm 18 jam, setelah itu bahan dicetak dengan ukuran $30 \mathrm{~cm}$ x $30 \mathrm{~cm}$ x $1 \mathrm{~cm}$. Kemudian bagian permukaan ditutup dengan tutup cetakan dan diberi tekanan pendahuluan. Selanjutnya cetakan diangkat secara perlahan-lahan setelah itu kedua sisi diberi baja $1 \mathrm{~cm}$ sebagai plat penahan untuk memperoleh ketebalan yang diinginkan pada saat pengempaan panas. Pengempaan panas dilakukan dengan menggunakan mesin kempa panas (hot press) dengan waktu pengempaan 15 menit dengan suhu pengempaan $180^{\circ} \mathrm{C}$ dengan tekanan kempa $25 \mathrm{~kg} / \mathrm{cm}^{2}$ (Suhaimi, 2018).

Papan partikel yang telah jadi kemudian dikondisikan selama 7 hari sebelum dipotong menjadi contoh uji. Pengujian sifat fisik dan sifat mekanik papan partikel dilakukan dengan mengacu pada standar JIS A 5908-2003 meliputi: kerapatan, kadar air, daya serap air, pengembangan tebal, modulus elastisitas (MOE), modulus patah (MOR), keteguhan rekat, dan kuat pegang sekrup. Pengujian keawetan terhadap rayap tanah Coptotermes curvignathus Holmgren dilakukan berdasarkan standar SNI 01.7207-2006. Parameter pengujian 
keawetan meliputi mortalitas rayap dan kehilangan berat sampel uji.

\section{HASIL DAN PEMBAHASAN}

Sifat Fisik Papan Partikel

Kerapatan Papan Partikel

Nilai rerata kerapatan berkisar antara $0,7147 \mathrm{gr} / \mathrm{cm}^{3} \sim 0,8802 \mathrm{gr} / \mathrm{cm}^{3}$. Kerapatan tertinggi terdapat pada papan partikel dengan kerapatan $0,8 \mathrm{gr} / \mathrm{cm}^{3}$ dan konsentrasi asam sitrat 30\% yaitu sebesar $0,8802 \mathrm{gr} / \mathrm{cm}^{3}$ dan kerapatan terendah terdapat pada papan partikel dengan kerapatan $0,7 \mathrm{gr} / \mathrm{cm}^{3}$ dengan konsentrasi asam sitrat $20 \%$ sebesar $0,7147 \mathrm{gr} / \mathrm{cm}^{3}$.

Nilai kerapatan papan partikel yang dihasilkan bervariasi, hal ini diduga karena penggunaan jumlah bahan yang berbeda menyebabkan nilai kerapatan papan partikel yang dihasilkan tidak sama. Semakin tinggi kerapatan menyeluruh dari suatu bahan baku tertentu maka semakin tinggi kekuatan papan (Haygreen dan Bowyer, 1996).

Semakin tinggi konsentrasi perekat yang digunakan maka semakin tinggi kerapatan papan partikel yang dihasilkan. Hal ini disebabkan karena semakin tinggi konsentrasi perekat akan menambah berat dari papan partikel yang dihasilkan. Shmulsky dan Jones (2011) dalam Maulana et al., (2015) berpendapat bahwa kerapatan papan partikel dipengaruhi oleh kerapatan bahan baku, konsentrasi perekat serta bahan tambahan lainnya dalam pembuatan papan partikel. Nilai kerapatan papan partikel yang dihasilkan dari penelitian disajikan pada Gambar 1 .

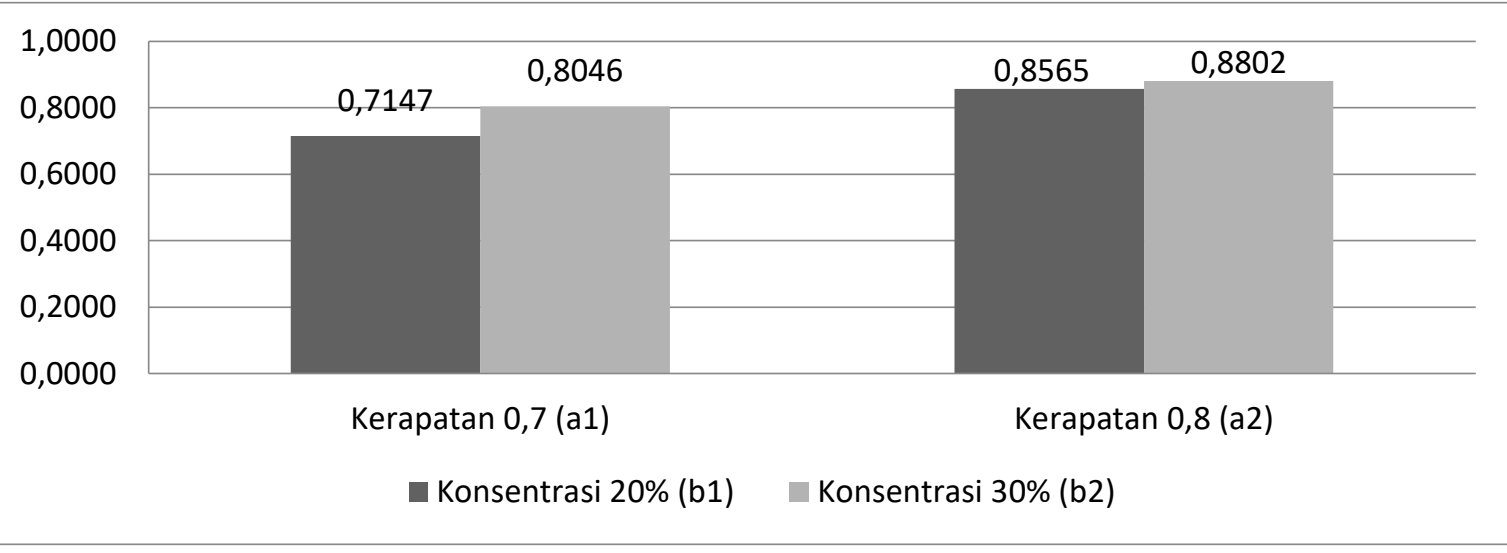

Gambar 1. Nilai Rerata Kerapatan Papan Partikel dari Limbah Kulit Batang Sagu Berdasarkan Kerapatan dan Konsentrasi Perekat Asam Sitrat yang Berbeda (The average values of density of particleboards made from bark fiber of Sago based on different densities and concentration of citric acid) 


\section{Kadar Air Papan Partikel}

Nilai rerata kadar air papan partikel berkisar antara 5,2808\% 6,1446\% . Kadar air tertinggi terdapat pada papan partikel dengan kerapatan $0,8 \mathrm{gr} / \mathrm{cm}^{3}$ dan konsentrasi asam sitrat $20 \%$ yaitu sebesar 6,1446\% dan kadar air terendah terdapat pada papan partikel kerapatan $0,7 \mathrm{gr} / \mathrm{cm}^{3}$ dan konsentrasi asam sitrat $30 \%$ yaitu sebesar 5,2808 \%. Nilai kadar air papan partikel yang dihasilkan dari penelitian memenuhi standar JIS A 5908-2003 yang berkisar antara 5\% sampai $13 \%$.

Semakin tinggi konsentrasi perekat maka semakin rendah pula kadar air, hal ini dikarenakan penambahan konsentrasi perekat akan membuat ikatan yang kuat antar partikel. Pencampuran aquades dalam melarutkan perekat asam sitrat akan meningkatkan kadar air yang kemudian dicampurkan kembali bersama dengan bahan yang membuat perekat masuk ke dalam pori-pori sagu. Namun, setelah bahan yang tercampur tadi masuk ke proses pengempaan dengan suhu $180^{\circ} \mathrm{C}$ dan waktu 15 menit maka kadar air dari bahan akan menguap untuk mencapai kadar air kesetimbangan. Hal ini sesuai dengan hasil penelitian Ruhendi dan Putra (2011) tentang sifat fisis dan mekanis papan partikel dari batang dan cabang kayu Jabon (Anthocephalus cadamba Miq) yang menyatakan bahwa semakin tinggi kadar perekat maka nilai kadar air suatu papan partikel akan semakin menurun. Nilai rata-rata kadar air papan partikel dari limbah kulit batang sagu pada faktor kerapatan dan konsentrasi asam sitrat yang berbeda disajikan pada Gambar 2.

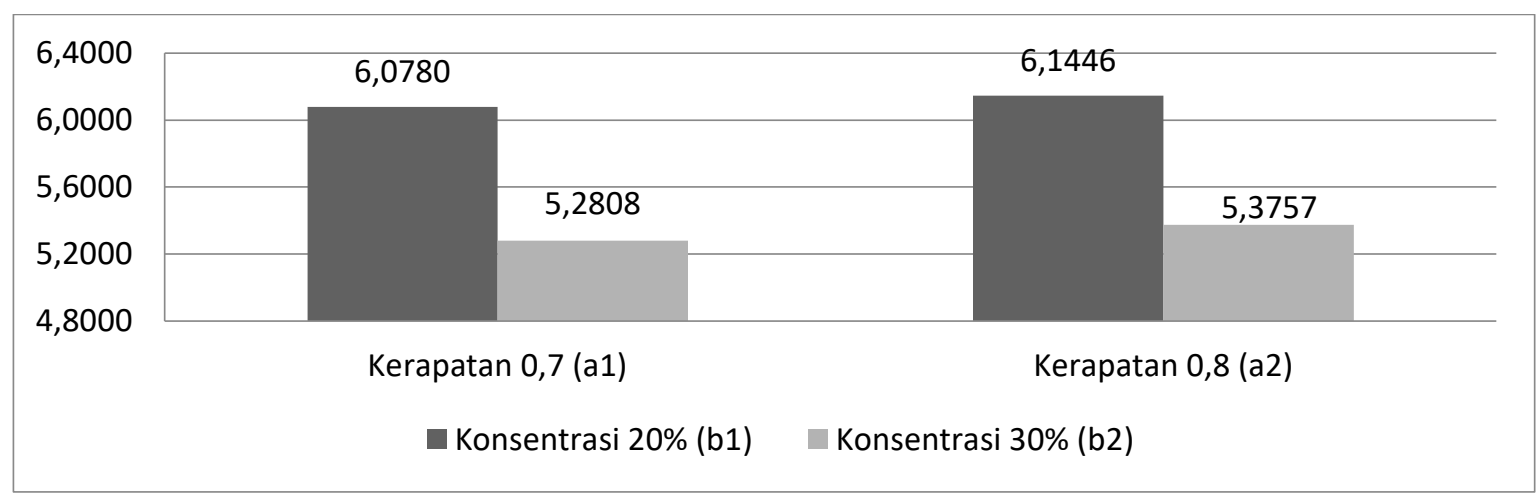

Gambar 2. Nilai Rerata Kadar Air Papan Partikel dari Limbah Kulit Batang Sagu Berdasarkan Kerapatan dan Konsentrasi Perekat Asam Sitrat yang Berbeda (The average values of water content of particleboards made from bark fiber of Sago based on different densities and concentration of citric acid) 


\section{Daya Serap Air Papan Partikel}

Nilai rerata daya serap air berkisar antara 28,8319\% 54,2482 \%. Kadar air tertinggi terdapat pada papan partikel kerapatan $0,7 \mathrm{gr} / \mathrm{cm}^{3}$ dan konsentrasi asam sitrat $20 \%$ yaitu sebesar 54,2482\% dan terendah terdapat pada papan partikel kerapatan $0,7 \mathrm{gr} / \mathrm{cm}^{3}$ dengan konsentrasi $30 \%$ sebesar $28,8319 \%$.

Semakin tinggi konsentrasi perekat maka nilai daya serap air akan menurun, hal ini dikarenakan perekat telah terlebih dahulu masuk ke dalam pori-pori bahan serat sagu sebelum dikempa panas menjadi papan partikel yang menyebabkan ketika pada proses pengujian daya serap air menyebabkan sedikitnya air yang masuk atau diserap oleh papan partikel terebut, hal ini dibenarkan oleh (Umemura et al,. 2011 dalam Widyorini et al,. 2012) menyatakan semakin banyak jumlah asam sitrat yang ditambahkan, maka semakin kuat terhadap ketahanan air. Nilai ratarata daya serap air papan partikel dari limbah kulit batang sagu pada faktor kerapatan dan konsentrasi asam sitrat yang berbeda disajikan pada Gambar 3 .

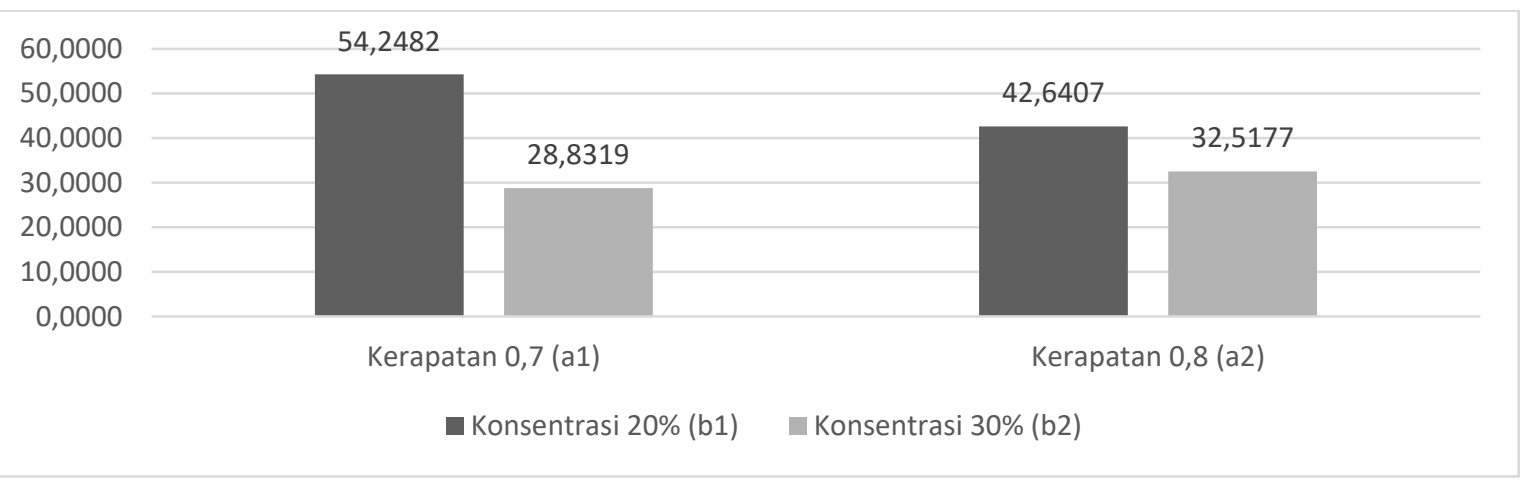

Gambar 3. Nilai Rerata Daya Serap Air Papan Partikel dari Limbah Kulit Batang Sagu Berdasarkan Kerapatan dan Konsentrasi Perekat Asam Sitrat yang Berbeda (The average values of water absorption of particleboards made from bark fiber of Sago based on different densities and concentration of citric acid)

\section{Pengembangan Tebal}

Nilai rerata pengembangan tebal papan partikel berkisar antara $12,2797 \%$ sampai 48,9664\%. Pengembangan tebal tertinggi terdapat pada papan partikel kerapatan $0,7 \mathrm{gr} / \mathrm{cm}^{3}$ dengan konsentrasi asam sitrat $20 \%$ sebesar $48,9664 \%$ dan terendah terdapat pada papan partikel kerapatan $0,7 \mathrm{gr} / \mathrm{cm}^{3}$ dengan konsentrasi asam sitrat $30 \%$ sebesar $12,279 \%$.
Tingginya pengembangan tebal papan partikel juga terjadi dikarenakan ketahanan perekat asam sitrat terhadap air yang kurang baik, Dumanauw (1990) dalam Kusuma (2016) menyatakan, bahwa jenis perekat yang berasal dari tumbuh-tumbuhan mempunyai daya tahan kelembaban yang sangat rendah 
serta keutuhan terhadap mikro organisme masih kurang.

Semakin bertambahnya kerapatan nilai pengembangan tebal akan semakin menurun, hal ini disebabkan karena papan partikel yang dihasilkan memiliki sedikit rongga untuk masuknya air. Proses perendaman air akan terlebih dahulu merusak ikatan-ikatan antara perekat dan partikel sehingga semakin lama terjadilah perubahan dimensi. Iswanto dkk (2005) mengemukakan bahwa pengembangan tebal ada hubungan erat dengan absorsi air, karena dengan semakin banyak air yang diserap oleh papan partikel dan memasuki struktur serat maka semakin besar perubahan dimensi yang terjadi. Nilai pengembangan tebal papan partikel disajikan pada Gambar 4.

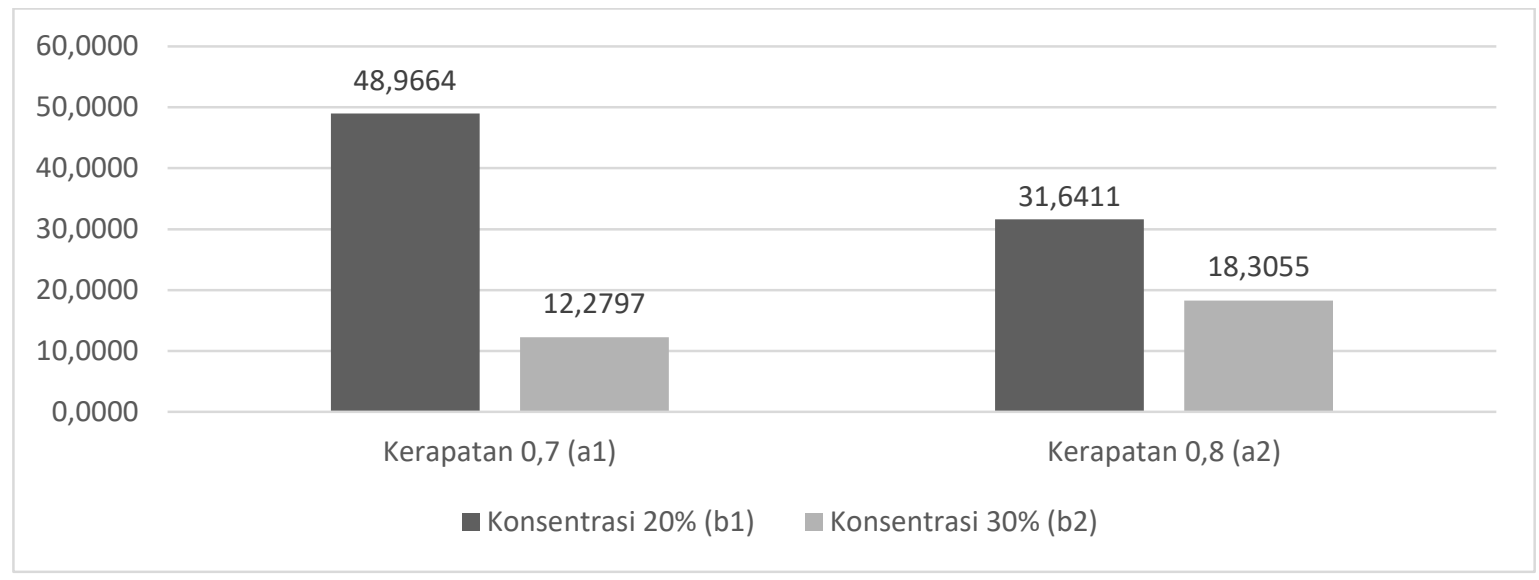

Gambar 4. Nilai Rerata Pengembangan Tebal Papan Partikel dari Limbah Kulit Batang Sagu Berdasarkan Kerapatan dan Konsentrasi Perekat Asam Sitrat yang Berbeda (The average values of thickness swelling of particleboards made from bark fiber of Sago based on different densities and concentration of citric acid)

Sifat Mekanik Papan Partikel

\section{Keteguhan Lentur (MOE)}

Nilai rerata keteguhan lentur (modulus of elasticity / MOE) berkisar antara $6195,0472 \quad \mathrm{~kg} / \mathrm{cm}^{2}$ sampai $17101,5706 \mathrm{~kg} / \mathrm{cm}^{2}$. Nilai keteguhan lentur tertinggi terdapat pada papan partikel kerapatan $0,8 \mathrm{gr} / \mathrm{cm}^{3}$ dengan konsentrasi $30 \%$ sebesar 17101,5706 $\mathrm{kg} / \mathrm{cm}^{2}$ dan terendah terdapat pada papan partikel kerapatan $0,7 \mathrm{gr} / \mathrm{cm}^{3}$ dengan konsentrasi $20 \%$ sebesar $\quad 6195,0472$ $\mathrm{kg} / \mathrm{cm}^{2}$.

Nilai keteguhan lentur papan partikel meningkat dengan makin tinggi target kerapatan dan konsentrasi asam sitrat. Hasil analisis sidik ragam menunjukkan kerapatan memberikan pengaruh sangat nyata terhadap nilai keteguhan lentur papan partikel. Hal ini disebabkan makin tinggi kerapatan kemampuan papan untuk menahan beban akan lebih kuat. Sejalan dengan penelitian Setyo (2008), yang 
menyatakan semakin tinggi kerapatan yang digunakan maka semakin tinggi pula nilai keteguhan lentur yang dihasilkan. Nilai keteguhan lentur papan partikel disajikan pada Gambar 5.

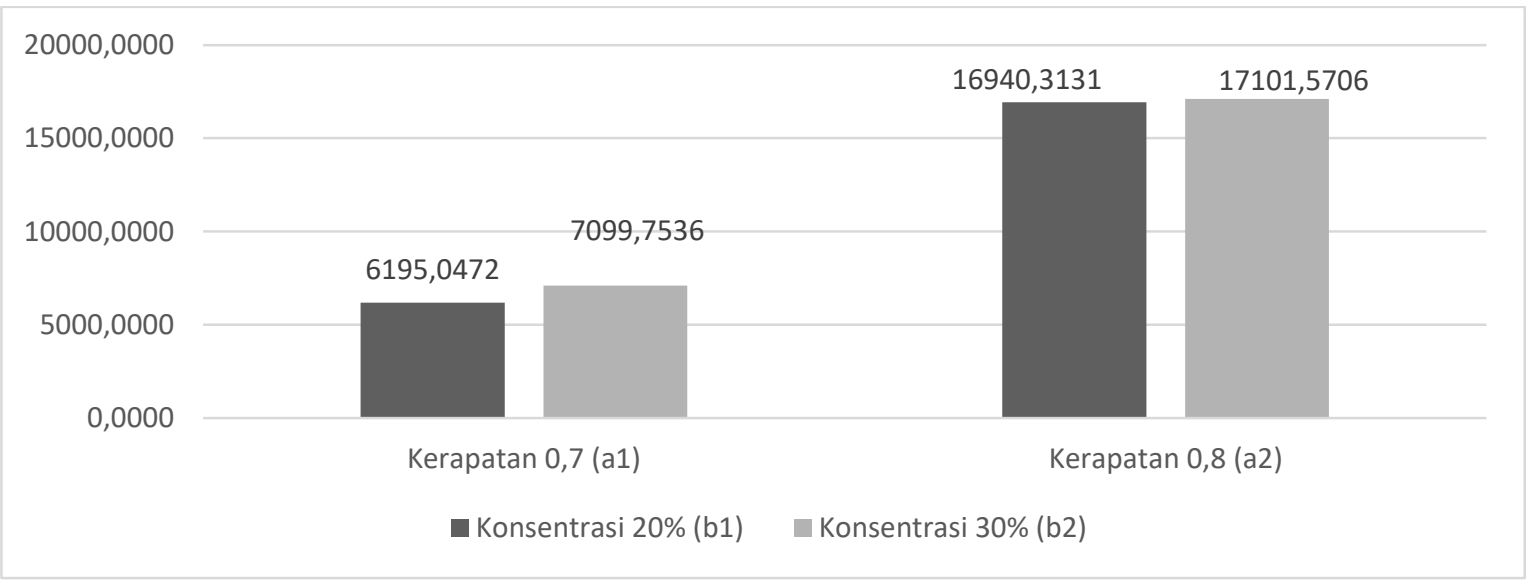

Gambar 5. Nilai Rerata Keteguhan Lentur Papan Partikel dari Limbah Kulit Batang Sagu Berdasarkan Kerapatan dan Konsentrasi Perekat Asam Sitrat yang Berbeda (The average values of modulus of elasticity of particleboards made from bark fiber of Sago based on different densities and concentration of citric acid)

Keteguhan Patah (MOR)

Nilai rerata keteguhan patah (Modulus of Rupture / MOR) papan partikel berkisar antara $43,6744 \mathrm{~kg} / \mathrm{cm}^{2}$ sampai $104,8997 \mathrm{~kg} / \mathrm{cm}^{2}$. Nilai keteguhan patah tertinggi terdapat pada papan partikel kerapatan $0,8 \mathrm{gr} / \mathrm{cm}^{3}$ dengan konsentrasi $30 \quad \%$ sebesar 104,8997 $\mathrm{kg} / \mathrm{cm}^{2}$ dan terendah terdapat pada papan partikel kerapatan $0,7 \mathrm{gr} / \mathrm{cm}^{3}$ dengan konsentrasi $20 \%$ sebesar $43,6744 \mathrm{~kg} / \mathrm{cm}^{2}$.

Faktor kerapatan dan konsentrasi perekat asam sitrat berbanding lurus hal ini dikarenakan tingginya kerapatan maka susunan partikel papan menjadi padat sehingga makin tinggi pula nilai keteguhan patahnya. Perekat yang dihasilkan juga sudah mengeras sampai kebagian tengah papan partikel karena proses pengempaan panas. Hasil tersebut memiliki kesamaan dengan penelitian Lestari (2018), yang berpendapat bahwa semakin tingginya kerapatan maka susunan partikel papan menjadi padat sehingga makin tinggi pula nilai keteguhan patahnya. Nilai rerata keteguhan patah papan partikel disajikan pada Gambar 6. 
JURNAL TENGKAWANG (2018)

Vol. 8 (2) : 88 - 101

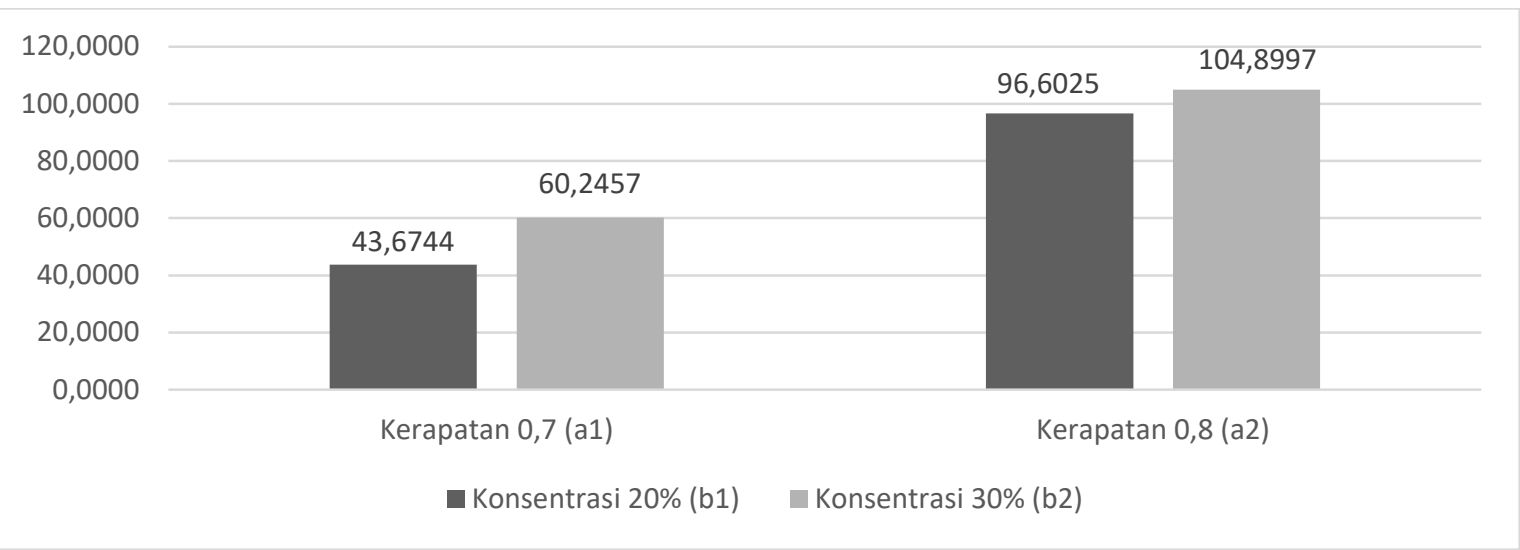

Gambar 6. Nilai Rerata Keteguhan Patah Papan Partikel dari Limbah Kulit Batang Sagu Berdasarkan Kerapatan dan Konsentrasi Perekat Asam Sitrat yang Berbeda (The average values of modulus of rupture of particleboards made from bark fiber of Sago based on different densities and concentration of citric acid)

\section{Keteguhan Rekat}

Nilai rerata keteguhan rekat papan partikel berkisar antara $0,7164 \mathrm{~kg} / \mathrm{cm}^{2}$ sampai $1,3810 \mathrm{~kg} / \mathrm{cm}^{2}$. Nilai keteguhan rekat tertinggi terdapat pada papan partikel kerapatan $0,8 \mathrm{gr} / \mathrm{cm}^{3}$ dengan konsentrasi $30 \%$ sebesar $1,3810 \mathrm{~kg} / \mathrm{cm}^{2}$ dan terendah terdapat pada papan partikel kerapatan $0,7 \mathrm{gr} / \mathrm{cm}^{3}$ dengan konsentrasi $20 \%$ sebesar $0,7164 \mathrm{~kg} / \mathrm{cm}^{2}$.

Peningkatan kerapatan dan konsentrasi perekat meningkatkan nilai keteguhan rekat papan partikel. Semakin banyak perekat maka daya rekat antar partikel juga meningkat sehingga nilai keteguhan rekat papan partikel meningkat. Peningkat an jumlah partikel yang dikarenakan peningkatan target kerapatan dapat meningkatkan keteguhan rekat papan partikel. Hubungan antara target kerapatan dan konsentrasi perekat terhadap peningkatan nilai keteguhan rekat papan partikel berbanding lurus. Mikael et al (2015) dalam Lestari (2018), menyatakan semakin seimbang (seragam) komposisi partikel yang digunakan, maka keteguhan rekatnya akan semakin baik. 
JURNAL TENGKAWANG (2018)

Vol. 8 (2) : 88 - 101

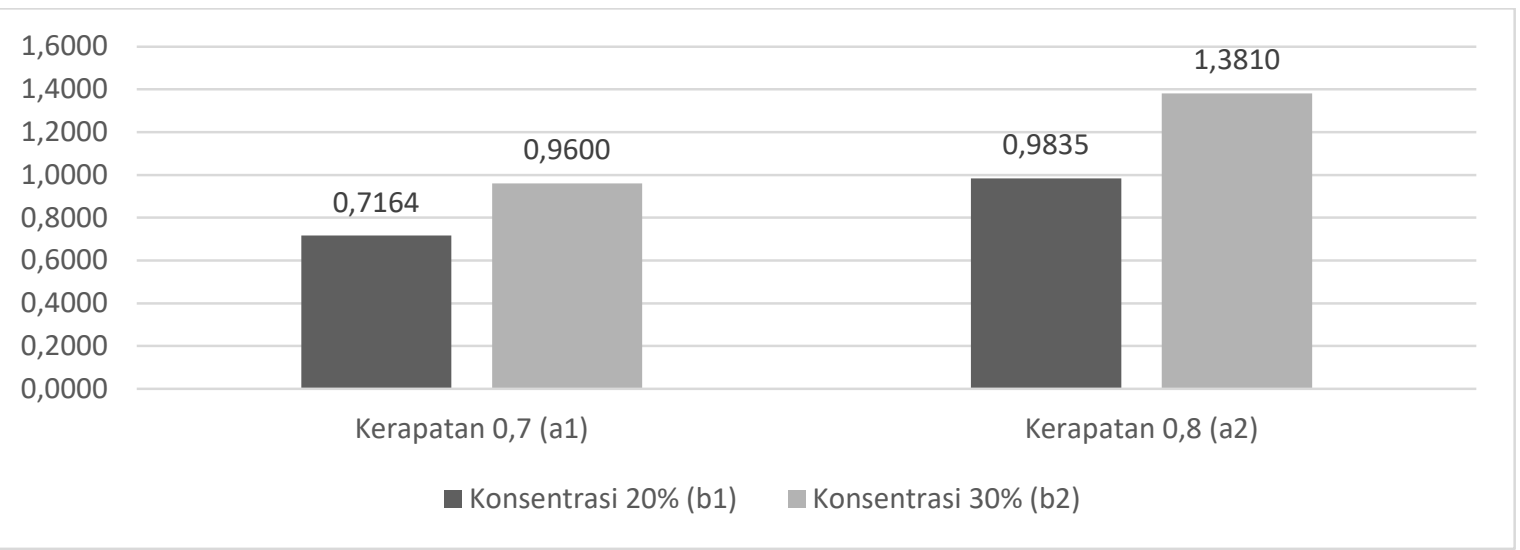

Gambar 7. Nilai Rerata Keteguhan Rekat Papan Partikel dari Limbah Kulit Batang Sagu Berdasarkan Kerapatan dan Konsentrasi Perekat Asam Sitrat yang Berbeda (The average values of internal bond of particleboards made from bark fiber of Sago based on different densities and concentration of citric acid)

\section{Kuat Pegang Sekrup}

Nilai rerata kuat pegang sekrup papan partikel berkisar antara $19,3752 \mathrm{~kg}$ sampai $31,7258 \mathrm{~kg}$. Nilai kuat pegang sekrup tertinggi terdapat pada papan partikel kerapatan $0,8 \mathrm{gr} / \mathrm{cm}^{3}$ dengan konsentrasi asam sitrat $30 \%$ sebesar $31,7258 \mathrm{~kg}$ dan terendah terdapat pada papan partikel kerapatan $0,7 \mathrm{gr} / \mathrm{cm}^{3}$ dengan konsentrasi asam sitrat 20\% sebesar 19,3752 kg.

Bertambahnya nilai kerapatan papan partikel dan konsentrasi perekat asam sitrat menghasilkan nilai kuat pegang sekrup yang tinggi. Hal ini diduga dengan tingginya kerapatan membuat banyaknya partikel bahan baku yang saling mengikat dan semakin tinggi konsentrasi perekat membuat ikatan yang semakin kuat antar partikel dan menghasilkan kekuatan dari nilai kuat pegang sekrup pada papan partikel semakin tinggi. Menurut Alghiffari (2008) dalam Maulana (2015), semakin tinggi kadar perekat semakin tinggi kuat pegang sekrup papan partikel, hal tersebut dikarenakan semakin kompaknya partikel dalam papan sehingga lebih kuat menahan sekrup. Nilai rerata kuat pegang sekrup papan partikel disajikan pada Gambar 8. 
JURNAL TENGKAWANG (2018)

Vol. 8 (2) : 88 - 101

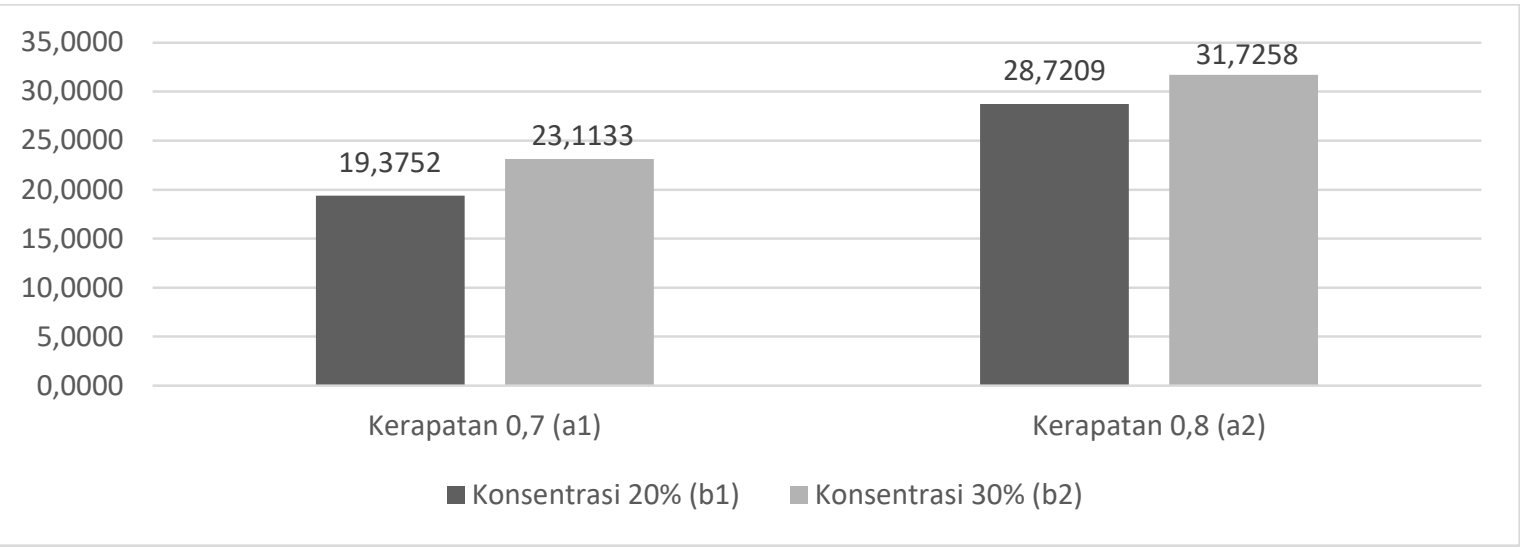

Gambar 8. Nilai Rerata Kuat Pegang Sekrup Papan Partikel dari Limbah Kulit Batang Sagu Berdasarkan Kerapatan dan Konsentrasi Perekat Asam Sitrat yang Berbeda (The average values of screw holding strenght of particleboards made from Bark Fiber of Sago based on different densities and concentration of citric acid)

\section{Keawetan Papan Partikel terhadap Rayap Coptotermes curvignathus Mortalitas Rayap}

Nilai rerata mortalitas rayap berkisar antara $94 \% \sim 100 \%$. Nilai mortalitas rayap tertinggi terdapat pada papan partikel kerapatan $0,8 \mathrm{gr} / \mathrm{cm}^{3}$ dengan konsentrasi asam sitrat 30\% sebesar $100 \%$ dan terendah terdapat pada papan partikel kerapatan $0,7 \mathrm{gr} / \mathrm{cm}^{3}$ dengan konsentrasi asam sitrat $20 \%$ sebesar $94 \%$.

Bertambahnya kerapatan papan partikel dan konsentrasi perekat asam sitrat menghasilkan nilai mortalitas rayap yang tinggi. Hal ini disebabkan dengan banyaknya partikel yang tercampur oleh perekat asam sitrat yang kemudian dikempa dengan suhu $180^{\circ} \mathrm{C}$ selama 15 menit menyebabkan meningkatnya kekerasan permukaan papan oleh perekat.
Permukaan papan partikel yang keras menyebabkan rayap sulit untuk mengkonsumsi papan partikel, dan hal ini diduga menjadi penyebab tingginya mortalitas rayap. Perbedaan konsentrasi asam sitrat menyebabkan peningkatan nilai mortalitas rayap. Penambahan asam sitrat menyebabkan mortalitas rayap yang tinggi (Widyorini et al, 2015).

Faktor lain yang menyebabkan tingginya nilai mortalitas rayap ialah faktor penguapan asam sitrat yang terkandung di papan partikel. Bau khas dari asam sitrat menyelimuti wadah uji rayap selama 21 hari. Hal ini yang menyebabkan kematian pada rayap karena rayap tidak memakan sampel uji papan partikel. Nilai rerata mortalitas rayap disajikan pada Gambar 9. 
JURNAL TENGKAWANG (2018)

Vol. 8 (2) : 88 - 101

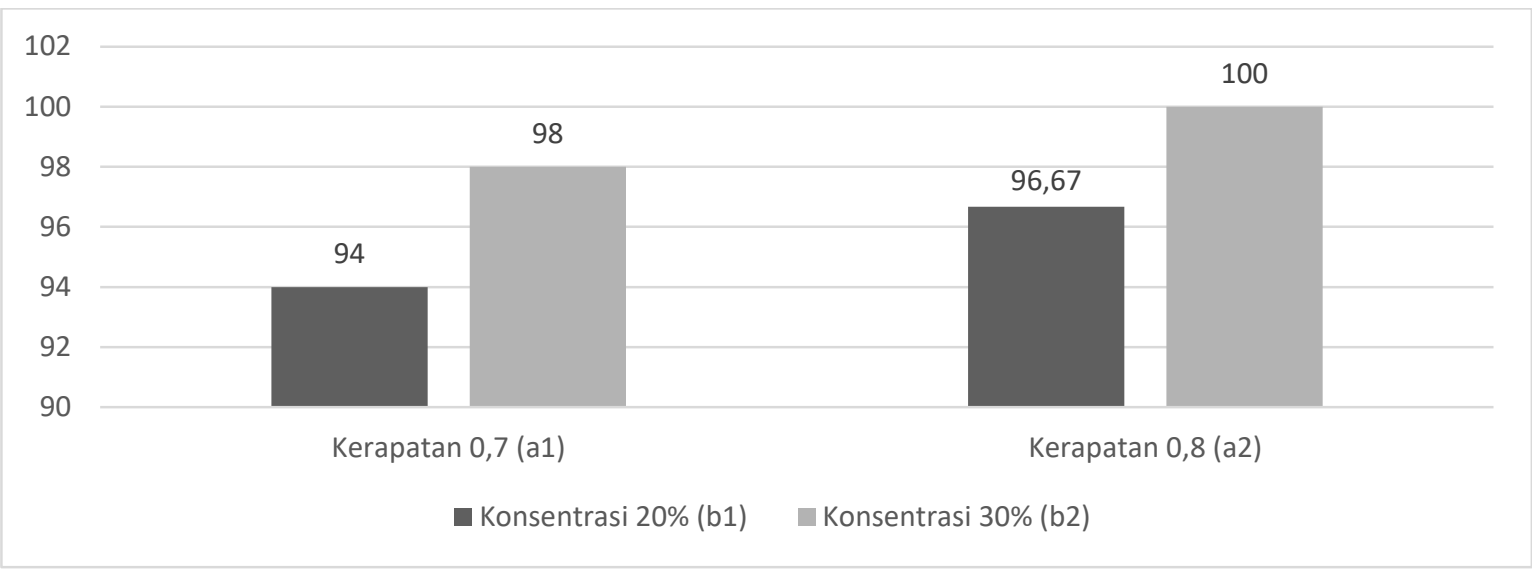

Gambar 9. Nilai Rerata Mortalitas Rayap Setelah Pengujian Pada Papan Partikel dari Limbah Kulit Batang Sagu Berdasarkan Kerapatan dan Konsentrasi Perekat Asam Sitrat yang Berbeda (The average values of termites mortality after evaluation on particleboards made from bark fiber of Sago based on different densities and concentration of citric acid)

\section{Kehilangan Berat Papan Partikel}

Nilai rerata kehilangan berat papan partikel setelah pengujian terhadap rayap tanah Coptotermes curvignathus berkisar antara $9,6166 \% \sim 18,5101 \%$. Nilai kehilangan berat tertinggi terdapat pada papan partikel kerapatan $0,7 \mathrm{gr} / \mathrm{cm}^{3}$ dengan konsentrasi asam sitrat 20\% sebesar $18,5101 \%$ dan terendah terdapat pada papan partikel kerapatan $0,8 \mathrm{gr} / \mathrm{cm}^{3}$ dengan konsentrasi asam sitrat $30 \%$ sebesar 9,6166\%.

Kerapatan papan merupakan salah satu faktor yang dapat mempengaruhi aktifitas konsumsi rayap. Papan dengan kerapatan yang tinggi cenderung lebih keras sehingga secara tidak langsung menjadi penghambat aktifitas konsumsi rayap secara fisik. Papan partikel dengan tingkat mortalitas rayap paling tinggi mengalami kehilangan berat paling rendah karena sedikitnya rayap yang melakukan aktifitas makan.

Papan partikel yang telah mengalami proses pengempaan pada suhu tinggi memiliki tingkat kerapatan yang berbeda dari luar ke tengah. Bagian tengah memiliki kerapatan paling rendah, sementara bagian luar memiliki kerapatan paling tinggi. Kerapatan dan kekerasan yang tinggi pada bagian luar papan nampaknya menjadi penghalang fisik (physical barrier) bagi rayap untuk menyerang papan (Suhasman et al., 2008). Nilai rerata kehilangan berat papan partikel akibat serangan rayap tanah disajikan pada Gambar 10. 
JURNAL TENGKAWANG (2018)

Vol. 8 (2) : 88 - 101

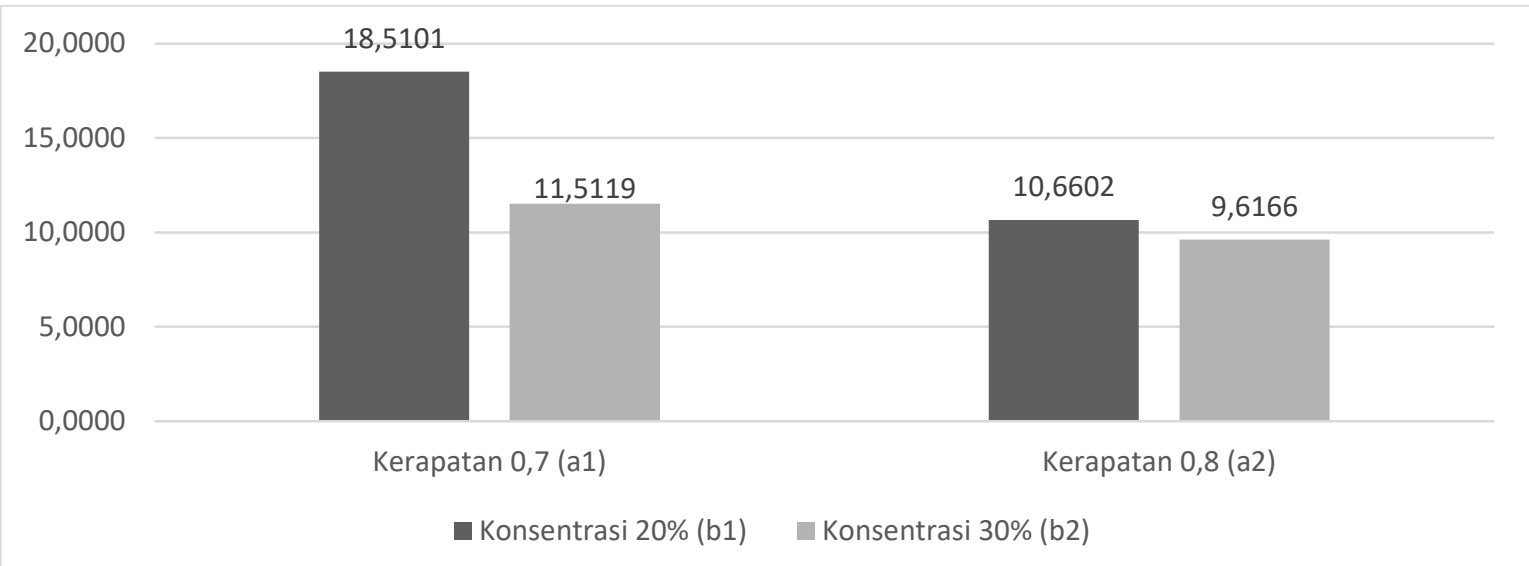

Gambar 10. Nilai Rerata Kehilangan Berat Papan Partikel dari Limbah Kulit Batang Sagu Berdasarkan Kerapatan dan Konsentrasi Perekat Asam Sitrat yang Berbeda (The average values of wood weight loss of particleboards made from bark fiber of Sago based on different densities and concentration of citric acid)

\section{Kesimpulan}

1. Papan partikel yang memenuhi standar JIS A 59082003 pada sifat fisik dan mekanik adalah kerapatan, kadar air, keteguhan patah dan kuat pegang sekrup.

2. Papan partikel yang dihasilkan memiliki nilai keawetan yang tinggi dan tahan terhadap serangan rayap tanah Coptotermes curvignathus Holmgren.

3. Papan partikel dengan perlakuan kerapatan $0,8 \mathrm{gr} / \mathrm{cm}^{3}$ dan konsentrasi asam sitrat $30 \%$ merupakan papan partikel dengan sifat fisik dan mekanik serta keawetan yang terbaik.

\section{Saran}

Perlu dilakukan penelitian untuk menguji keawetan papan partikel terhadap serangan jamur.

UCAPAN TERIMAKASIH
Penulis mengucapkan terima kasih kepada Nurhaida, S.Hut, M.Si dan Dr. Farah Diba, S.Hut, M.Si yang telah membimbing dalam penelitian dan penulisan makalah.

\section{DAFTAR PUSTAKA}

Haygreen J.G dan J.L Bowyer. 1996. Hasil Hutan dan Ilmu Kayu. Suatu Pengantar. Hadikusumo SA, penerjemah; Prawirohatmodjo S, editor. Terjemahan dari: Forest Product And Wood Science, An Introduction. Gajah Mada University Press.

Iswanto AH, Coto Z, Effendi K. 2008. Pengaruh Perendaman Partikel Terhadap Sifat Fisis Dan Mekanis Papan Partikel dari Ampas Tebu (Saccharum officinarum). Jurnal Perennial, 4(1) : 6-9.

Kusuma WDA. 2016. Pengaruh Perbedaan Suhu dan Lama Waktu Pengempaan Papan Partikel Berbahan Baku Kulit Batang Sagu 
degan Perekat Gambir (Uncaria gambir, Roxb) Terhadap Sifat Fisis dan Mekanis. Skripsi Fakultas Teknologi Pertanian. Universitas Andalas Padang.

Lestari M, Setyawati D, Nurhaida. 2018. Karakteristik Papan Partikel dari Ampas Sagu dan Perekat Asam Sitrat Berdasarkan Kerapatan Papan. Jurnal Hutan Lestari Vol. 6 (2) : $428-437$

Maloney, T.M. 1993. Modern Particle Board and Dry Process Fiberboard Manufacturing, USA : Miller Freeman Publication, Inc

Maulana D, Dirhamsyah, Setyawati D. 2015. Karakteristik Papan Partikel dari Batang Pandan Mengkuang (Pandanus atrocarpus Griff) Berdasarkan Ukuran dan Konsentrasi Ureafomaldehida. Jurnal Hutan Lestari 3: 247-258

Nandika. D., Y. Rismayadi dan F. Diba. 2003. Rayap Biologi dan Pengendaliannya. Universitas Muhammadiyah Surakarta. Surakarta.

Ruhendi S dan Putra E. 2011. Sifat Fisis dan Mekanis Papan Partikel dari Batang dan Cabang Kayu Jabon (Anthocephalus cadamba Miq). Jurnal Ilmu dan Teknologi Hasil Hutan 4(1): 14-21. Bogor.
Setyo H., Nor Intang dan Sudibyo, Gathot Heri. 2008. Variasi Komposisi Kerapatan Partikel Dan Jumlah Perekat Terhadap Karakteristik Papan Komposit Limbah Kayu Aren dan Serbuk Gergaji. Dinamika Rekayasa Vol 4, No 2:99-114.

Suhaimi, Setyawati D, Nurhaida. 2018. Kualitas Papan Partikel dari Serat Kulit Batang Sagu (Metroxylon Spp) dengan Perekat Alami Asam Sitrat Berdasarkan Waktu Kempa. Jurnal Hutan Lestari. Vol. 6(3) : 535-547.

Suhasman, Massijaya, Muh. Yusram, Hadi, Yusuf Sudo, Arif, Astuti. 2008. Ketahanan Papan Komposit dari Limbah Kayu Sengon dan Karton Terhadap Rayap Kayu Kering dan Rayap Tanah. PERENNIAL Vol. 4, No. 1:28-35

Widyorini R, Prayitno TA, Yudha AP, Setiawan BA, dan Wicaksono BH. 2012. Pengaruh Konsentrasi Asam Sitrat dan Suhu Pengempaan Terhadap Kualitas Papan Partikel dari Pelepah Nipah. Jurnal Ilmu Kerhutanan. Vol. VI. No. 1: 61-70.

Widyorini R, Yudha AP, Lukmandaru G, dan Prayitno TA. 2015. Sifat Fisik, Mekanika, dan Ketahanan Papan Partikel Bambu dengan Perekat Asam Sitrat Terhadap Serangan Rayap Kayu Kering. Jurnal Ilmu Kehutanan. Vol. IX. No. 1:12-22. 